\title{
Microbial Quality of three Imported Fresh Locally Produced Marine Fishes in Al-Faw City, Basrah, Iraq
}

Amal S. Al-Sheraa*

Department of Marine Biology, Marine Science Center, Basrah University, Basrah, Iraq

\begin{abstract}
The present study was conducted to determine microbial quality have been measured in gills and gut tissues in three imported fishes samples obtained from trawl fishing boats in Al-Faw city, Basrah, Iraq. In this study, tissues samples were collected from 80 fish samples of three fresh marine fish species: silver pomfret Pampus argenteus (Euphrasen, 1788); Oriental Sole Brachirus orientalis (Bloch \& Schneider, 1801) and Yellowfin seabream, Acanthopagrus latus (Houttuyn,. 1782) were collected from trawl fishing boats of Al-Faw city during period from January 2017 to April 2017. Samples of three marine fish's species were examined for the fecal coliforms. Level of fecal coliforms was higher on tissues samples of Pampus argenteus were total number of fecal coliform identified were in 18 samples (22.50\%) and in Brachirus orientalis fecal coliforms bacteria species were found in 11 samples $(13.75 \%)$, while the lowest level of fecal coliforms was found in tissues samples of Acanthopagrus latus 4 (5\%). To find out pathogenic bacteria culturing technique was used followed by staining for identification of bacterial species. In this study determination of coliforms especially Escherichia coli, Pseudomonas aeruginosa and Salmonella sp., three fecal coliforms Bacteria species were found (E. coli, $P$. aeruginosa, and Salmonella $s p$.) in tissues of three fish species samples in this study, E. coli was mostly present specie and it was identified in 16 tissues samples of $P$. argenteus $(20.00 \%)$ followed by tissues samples of $B$. orientalis in 14 samples $(17.50 \%)$, while were found in 10 tissues samples of $A$. latus $(12.50 \%)$.
\end{abstract}

Keywords: Marine fish; Microbial quality; Fecal coliforms

\section{Introduction}

Microbiological quality and safety of freshly caught fish depends on the hygienic quality of the surrounding aquatic environment. Fish are susceptible to contamination, especially those from freshwater environments characterized by slow water exchange and high anthropogenic contamination [1]. In the aquatic environment microorganisms spread easily between habitats and hosts. Fish may obtain bacteria from water, sediment and food organisms; therefore, the microbiological contamination of fish species may be affected by its feeding behavior, available food and environmental pollution $[2,3]$.

Even though, sea foods are nutritive, they act as a vehicle for the pathogenic bacteria naturally occurring in the aquatic environment referred to as indigenous or derived from the postharvest contamination $[4,5]$. It is considered that the quality of seafood depends on the quality of water where the fishes are caught and the sanitary conditions of the landing centre. Microorganisms occur nearly everywhere in nature and occupy an important place in the life of human. The human activities had a great impact in coastal areas in the last two decades with the effects of industrialization, intensive agriculture and coastal engineering gave serious threat to marine life [6] that led to environmental pollution.

A number of studies have been carried out on microbial flora associated with marine $[7,8]$ or aquacultured fish $[9,10]$. However, information on microbiological contamination of freshwater fish from natural population is scarce.

The aims of this study were to evaluate the microbiological quality of three fresh marine fishes: silver pomfret Pampus argenteus, Oriental Sole Brachirus orientalis and Yellowfin seabream, Acanthopagrus latus were obtained from trawl fishing boats of Al-Faw city during period from January 2017 to April 2017, and to determine the presence of fecal coliforms especially: Escherichia coli, Pseudomonas aeruginosa and Salmonella sp.

\section{Material and Methods \\ Collection of fish samples}

Fish samples were collected during period from January 2017 to April 2017 from trawl fishing boats in Al-Faw city in Basrah governorate. Overall, 240 fish samples were collected: 80 fish for each species including: three fresh marine fishes: silver pomfret Pampus argenteus, Oriental Sole Brachirus orientalis and Yellowfin seabream, Acanthopagrus latus. Samples were placed in sterile plastic bags and transported to the laboratory in ice boxes. All samples were analyzed within $24 \mathrm{~h}$ after time of caught, keeping them under refrigerated conditions in the meantime.

\section{Isolation and Identification of Bacteria}

\section{Microbial analysis}

The microbial content of the fish samples was enumerated by standard plate count technique using $100 \mathrm{ml}$ aliquots of appropriate dilution pour plated onto Nutrients agar, MacConkey, Mannitol salt agar and Salmonella-Shigella agar for bacteria. All plates for bacteria isolation were incubated at $37^{\circ} \mathrm{C}$ for 24 to $48 \mathrm{~h}$. Individual colonies were purified and identified by morphological and biochemical techniques [11].

*Corresponding author: Amal S. Al-Sheraa, Department of Marine Biology, Marine Science Center, Basrah University, Basrah, Iraq, Tel: +9647704725415; E-mail: alsheraaamal79@gmail.com

\section{Received March 22, 2018; Accepted April 26, 2018; Published April 30, 2018}

Citation: Al-Sheraa AS (2018) Microbial Quality of three Imported Fresh Locally Produced Marine Fishes in Al-Faw City, Basrah, Iraq. J Aquac Res Development 9: 531. doi: 10.4172/2155-9546.1000531

Copyright: ( 2018 Al-Sheraa AS, et al. This is an open-access article distributed under the terms of the Creative Commons Attribution License, which permits unrestricted use, distribution, and reproduction in any medium, provided the original author and source are credited. 


\section{Statistical analysis}

Analysis of the data was carried out by using SPSS (20.0 version) for the mean standard deviation at $5 \%$ level of significance.

\section{Results}

\section{Frequency of occurrence of the bacterial isolates}

The most bacterial isolates of fecal coliforms were belongs to three genera; Pseudomonas, Escherichia and Salmonella.

A total of 80 samples of each species of fishes were collected from trawl fishing boats in Al-Faw city at four months in this study during 16/1/ 2017 to 22/4/ 2017. (20 fish samples at each month), After a careful experimental work, stand top for having most number of fecal coliforms found in gills and gut tissues samples of three species fishes: Pampus argenteus were with highest total number of coliform identified were in 18 samples (22.50\%) and in Brachirus orientalis fecal bacteria species were found in 11 samples (13.75\%), while in Acanthopagrus latus were found in $9(11.25 \%)$ as shown in Table 1.

Three fecal coliforms Bacteria species were found (E. coli, P. aeruginosa, Salmonella sp.) in gills and gut tissues of three fish species samples in this study, E. coli was mostly present specie and it was identified in 16 tissue samples of $P$. argenteus (20.00\%) followed by tissues samples of $B$. orientalis in 14 samples (17.50\%), while in 10 samples of tissues in A. latus (12.50\%) as shown in Table 2.

The numbers of cultivable bacteria present in gills and gut of three fresh marine fishes species showing monthly changes between stations are shown in Figures 1 and 2.

The monthly total bacterial counts in tissues of gills and gut samples of three fishes species showed maximum count was $82.31 \times 10^{3}$ CFU/100 in April 2017 and minimum count was $1.36 \times 10^{3} \mathrm{CFU} / 100$ $\mathrm{ml}$ in February 2017. Fecal coliform count in isolates from tissues of gills was from $1.36 \times 10^{3}$ to $33.54 \times 10^{3} \mathrm{CFU} / 100 \mathrm{ml}$ in three marine fishes species, and the highest value was found in A. latus, while the lowest in B. orientalis.

Fecal coliform count ranged from $12.71 \times 10^{3} \mathrm{CFU} / 100 \mathrm{ml}$ to 82.31 $\times 10^{3} \mathrm{CFU} / 100$ on tissues of gut of of three marine fishes species. Tissues of gut of $A$. latus, and B. orientalis was more contaminated than gills, and the lowest count was identified in B. orientalis, while the highest in $P$. argenteus (Table 2). The fecal coliform count in $P$. argenteus, samples was lower $(\mathrm{p}<0.05)$ in comparison with $A$. latus and B. orientalis. Also contamination of gut with fecal coliform was significantly higher in $B$. orientalis, than in $P$. argenteus $(\mathrm{p}<0.05)$.

\begin{tabular}{|c|c|c|c|c|c|}
\hline Variables & January & February & March & April & Total samples \\
\hline Pampus argenteus & 3 & 4 & 3 & 6 & $18(22.50 \%)$ \\
\hline Brachirus orientalis & 0 & 2 & 4 & 5 & $11(13.75 \%)$ \\
\hline Acanthopagrus latus & 0 & 3 & 2 & 4 & $9(11.25 \%)$ \\
\hline
\end{tabular}

Table 1: Total no of infected samples of three fishes species reported monthly.

\begin{tabular}{|c|c|c|c|c|}
\hline Variables & $\begin{array}{c}\boldsymbol{P} . \\
\text { argenteus }\end{array}$ & B. orientalis & A. latus & $\begin{array}{c}\text { Total } \\
\text { samples }\end{array}$ \\
\hline Total samples collected & 80 & 80 & 80 & 240 \\
\hline Total Infected samples & 22 & 27 & 14 & 63 \\
\hline E. coli & $16(20 \%)$ & $14(17.50 \%)$ & $10(12.50 \%)$ & $40(16.40 \%)$ \\
\hline P. aeruginosa & 4 & 9 & 3 & 16 \\
\hline Salmonella sp. & 2 & 2 & 0 & 4 \\
\hline
\end{tabular}

Table 2: Total number of microorganisms found in samples tissues of three fishes species collected from trawl fishing boats in Al-Faw city.

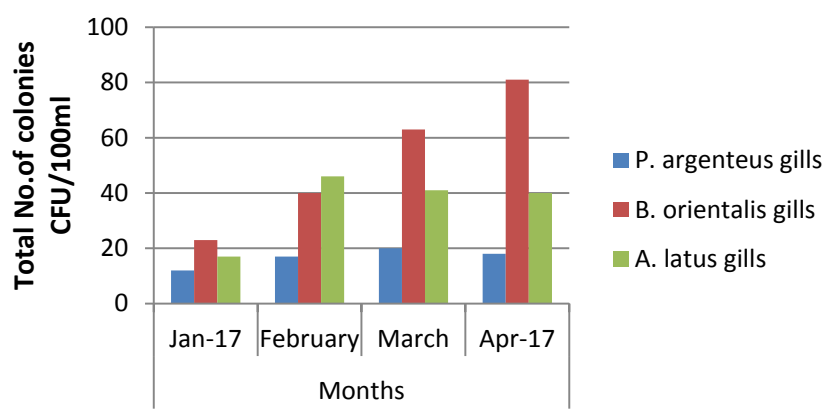

Figure 1: Total number of faecal bacterial isolates from gut of three marine fish species (CFU/100 ml)

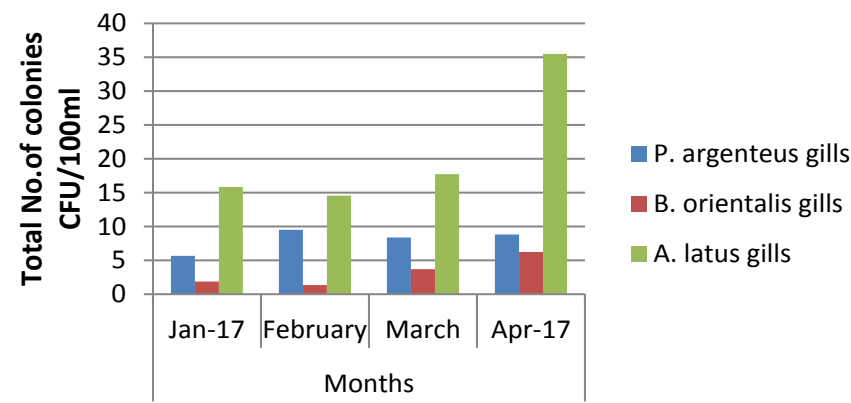

Figure 2: Total number of faecal bacterial isolates from gills of three marine fish species (CFU/100 ml)

\section{Discussion}

The presence of the coliform group of bacteria, mainly Citrobacter, Enterobacter, Escherichia and Klebsiella in fish and fish products presents a health hazard to humans $[3,12,13]$. Allen and Hepher [14] have stated that most of the epidemics attributed to wastewater sources are from raw sewage gaining access to food eaten directly by man, or from contamination of water supply systems by untreated sewage. Olayemi et al. [15] have reported that the presence of faecal coliform in fish intended for human consumption may constitute a potential danger not only in causing disease, but also because of the possible transfer of antibiotic resistance from aquatic bacteria to human infecting bacteria from nonaquatic sources. Some human pathogens such as Aeromonas, Escherichia, Klebsiella, Pseudomonas, Salmonella and Vibrio.

High counts of fecal coliforms and the prevalence of pathogenic bacteria in fish could be linked to contamination from surrounding water environment. However, similar results were reported in study of Gaertner et al., in the USA, who found the prevalence of $33 \%$ of Salmonella spp. in the guts of different fish (largemouth bass Micropterus salmoides, channel catfish Ictalurus punctatus, common carp Cyprinus carpio, and suckermouth catfish Hypostomus plecostomus) caught at the downstream site of San Marcos river in Texas [16]. Also, Miettinen and Wirtanen [17] studied 510 rainbow trout from fish farms in lakes and sea areas around Finland and in their study the prevalence of Listeria spp. in fish gill, viscera and skin varied greatly between fish farms from 0 to $75 \%$. In the investigation by Davies et al. [18], 23\% of fresh salmon (Salmo salar) and trout (Oncorhyncus mykiss) from Great Britain contained Y. enterocolitica.

\section{Conclusion}

The results of our study showed that fecal coliforms bacteria could 
Citation: Al-Sheraa AS (2018) Microbial Quality of three Imported Fresh Locally Produced Marine Fishes in Al-Faw City, Basrah, Iraq. J Aquac Res Development 9: 531. doi: 10.4172/2155-9546.1000531

Page 3 of 3

contaminate the gills and gut of freshly caught Brachirus orientalis and Acanthopagrus latus in high numbers in comparison with Pampus argenteus. These tissues in this study showed higher concentrations of pathogens, such as E. coli, P. aeruginosa and Salmonella sp. in three fishes species freshly caught in Al-Faw city. Public health must therefore be of prime concern when dealing with fishes species and its products.

\section{Authors' Contributions}

All authors in this paper have contributed equally toward the publication of this paper

\section{Acknowledgements}

We would like to thank the members of the Marine Biology Department, Marine Sciences Center, Basrah University, for help me in accomplishing this work and for their valuable advice and suggestions.

\section{References}

1. Orban E, Nevigato T, Masci M, Di Lena G, Casini I, et al. (2007) Nutritional quality and safety of European perch (Perca fluviatilis) from three lakes of Central Italy. Food chemistry 100: 482-490.

2. Olafsen JA (2001) Interactions between fish larvae and bacteria in marine aquaculture. Aquaculture 200: 223-247.

3. Geldreich EE, Clarke NA (1966) Bacterial pollution indicators in the intestinal tract of freshwater fish. Applied Microbiology 14: 429-437.

4. Wallace BJ, Guzewich JJ, Cambridge M, Altekruse S, Morse DL (1999) Seafood-associated disease outbreaks in New York, 1980 1994. Am J Prev Med 17: 48-54

5. Gillespie IA, Adak GK, O Brien SJ, Brett MM, Bolton FJ (2001) General outbreaks of infectious intestinal disease associated with fish and shellfish. England and Wales. Commun Dis Public Health 4: 117-123.

6. His E, Beias R, Seaman MNL (1999) The assessment of marine pollutionbioassays with bivalve embryos and larvae. Adv Mar Biol 37: 1-178.
7. Alexopoulos A, Plessas S, Voidarou C, Noussias H, Stavropoulou E, et al (2011) Microbial ecology of fish species on growing in Greek sea farms and their watery environment. Anaerobe 17: 264-266.

8. Al-Harbi AH, Uddin N (2005) Bacterial diversity of tilapia (Oreochromis niloticus) cultured in brackish water in Saudi Arabia. Aquaculture 250: 566-572.

9. Gonzalez CJ, Lopez-Diaz TM, Garcia-Lopez ML, Prieto M, Otero A (1999) Bacterial microflora of wild brown trout (Salmo trutta), wild pike (Esox lucius) and aqua-cultured rainbow trout (Oncorhynchus mykiss). J Food Protect 62 1270-1277.

10. Austin B (1983) Bacterial microflora associated with a coastal, marine fishrearing unit. Journal of Marine Biological Association of the United Kingdom 63: $585-592$.

11. Holt JG, Greig NR, Sneath PHA, Williams ST (1994) Bergey s Manual of Determinative Bacteriology 9 th ed. Williams and Williams. Baltimore, Maryland, USA.

12. Fapohunda AO, MacMillan KW, Marshall DL, Waites WM (1994) Growth of selected cross-contaminating bacterial pathogens on beef and fish at 15 and 350C. J Food Protect 57: 337-340.

13. Van Duijn JC (1973) Diseases of fishes, (3rd edn). Butterworth Co. Ltd London, UK.

14. Allen GH, Hepher B (1969) Recycling of wastes through aquaculture and constraints to wider application. In: Advances in aquaculture Pillay TVR and Dill WA, Eds. Oxford, Fishing News Books, England, p: 478-487.

15. Olayemi AB, Adebayo O, Ojo AO (1991) Microbial flora of six freshwater fish species from Asa River, Ilorin, Nigeria. Rev Biol Trop 39: 165-167.

16. Gaertner J, Wheeler PE, Obafemi S, Valdez J, Forstner MR, et al. (2008) Detection of Salmonellae in fish in a natural river system. J Aquat Anim Health 20: $150-157$

17. Miettinen H, Wirtanen G (2005) Prevalence and location of Listeria monocytogenes in farmed rainbow trout. Int J Food Microbiol 104: 135-143.

18. Davies AR, Capell C, Jehannoc D, Nychasd GJE, Kirby RM (2001) Incidence of foodborne pathogens on European fish. Food Control 12: 67-71. 